\title{
Comparison of Natural Gas Hydrocarbon Dewpointing Control Methods
}

\begin{abstract}
Abdelaziz A. Noaman ${ }^{1, ~ *, ~ E b r a h i e m ~ E . ~ E b r a h i e m ~}{ }^{1}$
${ }^{1}$ Chemical Engineering Department, Faculty of Engineering, Minia University, Minia, Egypt.

\section{Abstract}

Natural gas dew point is a very important quality parameter. It is specified in predetermined mandatory specifications for the producers through transmission and distribution companies to market. Several problems in gas transmission lines may be caused by the hydrocarbon liquid dropout. These include increase in pressure drop, line capacity reduction, and equipment problems (e.g. compressor damage). Avoiding liquid dropout, the operating current specifications of gas transmission lines require to be operated above the dew point of hydrocarbon (DPH) or cricondentherm hydrocarbon dew point (CHDP).

This paper compares the different methods for natural gas hydrocarbon dew-pointing that are widely applied in industry and choose the best method for a gas project to achieve the required hydrocarbon dew point of the export gas. These methods are Joule-Thomson expansion (J-T), turbo expansion, mechanical refrigeration, Pressure Swing Adsorption (PSA) and thermally Regenerated Adsorption (TSA). The comparison was made to choose the best applicable method needed for a gas project to achieve the required export gas specifications. It was found that the mechanical refrigeration method is preferred due to its numerous advantages.
\end{abstract}

Keyword: Hydrocarbon dew point, Joule-Thomson expansion, turbo expander, PSA, TSA, $C P F$.

\section{Introduction}

Natural gas dew point is an important operation parameter. Frequently, it is being used as a quality parameter. This requirement begins with the requirements of a quality product and may be at risk of losing their operating capacity if the gas quality slips [1].

Dustman et. al. state that light hydrocarbon liquids recovery from natural gas streams can range from simple dew point control to deep ethane extraction. Also, the desired degree of liquid recovery has a profound effect on process selection, complexity and cost of the processing facility [2].

Hydrocarbon dew point is the temperature at which the condensates begin to form when natural gas is cooled at constant pressure. In gas pipeline transmission, the presence of liquid hydrocarbons in grouping with traces of moisture primes to the hydrate formation as virtual solid masses [3]. Under the 


\section{Vol. 40, No. 2. July 2021}

operating conditions of high flow and pressure in pipeline, these hydrates can cause harmful damage to compressors and restrict or even block pipelines [4].

There is always a hydrocarbon condensation risk in natural gas transmission pipelines. This causes an increase in pressure drop is due to the condensation of hydrocarbons and will introduce operational problems resulting from two-phase flow [5]. It is necessary to prevent condensation by keeping the temperature and pressure of natural gas above the dew point to have a single-phase region. In this context, the optimal control of the hydrocarbon dew point is necessary for economical, operational and safety reasons [6].

\subsection{Objective}

The main objective of this work is to compare all-natural gas hydrocarbon dewpointing control methods applied in the industry and choose the best method for the development project to achieve the export gas specifications. The process gas contains heavy components and requires hydrocarbon dewpointing facilities to be provided at the $\mathrm{CPF}$ to meet the gas export specification of $10.5^{\circ} \mathrm{C}$ at any pressure.

There exists different gas hydrocarbon dewpointing control methods available in the market to remove the heavy hydrocarbon from the feed gas and comply with the required gas specifications in terms of the required hydrocarbon dewpoint.
The available different methods for natural gas hydrocarbon dewpointing control that are widely applied in industry are Joule-Thomson expansion (J-T), turbo expansion, mechanical refrigeration, Pressure Swing Adsorption (PSA) and thermally Regenerated Adsorption (TSA)

The comparison of all these methods should be based on the following items: -

- Energy costs.

- Market conditions (materials cost, consumables costs).

- Technology evolution with time.

- Company experience with a certain technology.

\section{Gas Project Description}

Figure 1 reveals the major processing units which make up the central processing facility CPF. The gas project consists of eight wells, a gathering system and CPF, where the production stream from the various fields will be separated into condensate and dew pointed gas products for export. The gas processing involves inlet facilities for liquid separation, mercury removal unit, $\mathrm{CO}_{2}$ removal unit, dehydration unit, and a hydrocarbon dewpointing unit to meet the export gas specifications.

The condensate separated from the gas in the inlet facilities is stabilized to meet the RVP specification for export condensate. The gas will be exported via export gas pipeline and treated in a dedicated Liquefied Petroleum Gas (LPG) extraction facility to commercial 
specification required for end user Mercury has been detected up to $70 \mathrm{ng} / \mathrm{Sm}^{3}$ in consumption. The condensate will be some well samples. Well samples are reported exported via export pipeline to the oil to contain no elemental Sulphur, no wax and terminal. no paraffin. Also, the $\mathrm{H}_{2} \mathrm{~S}$ content of the wells is zero

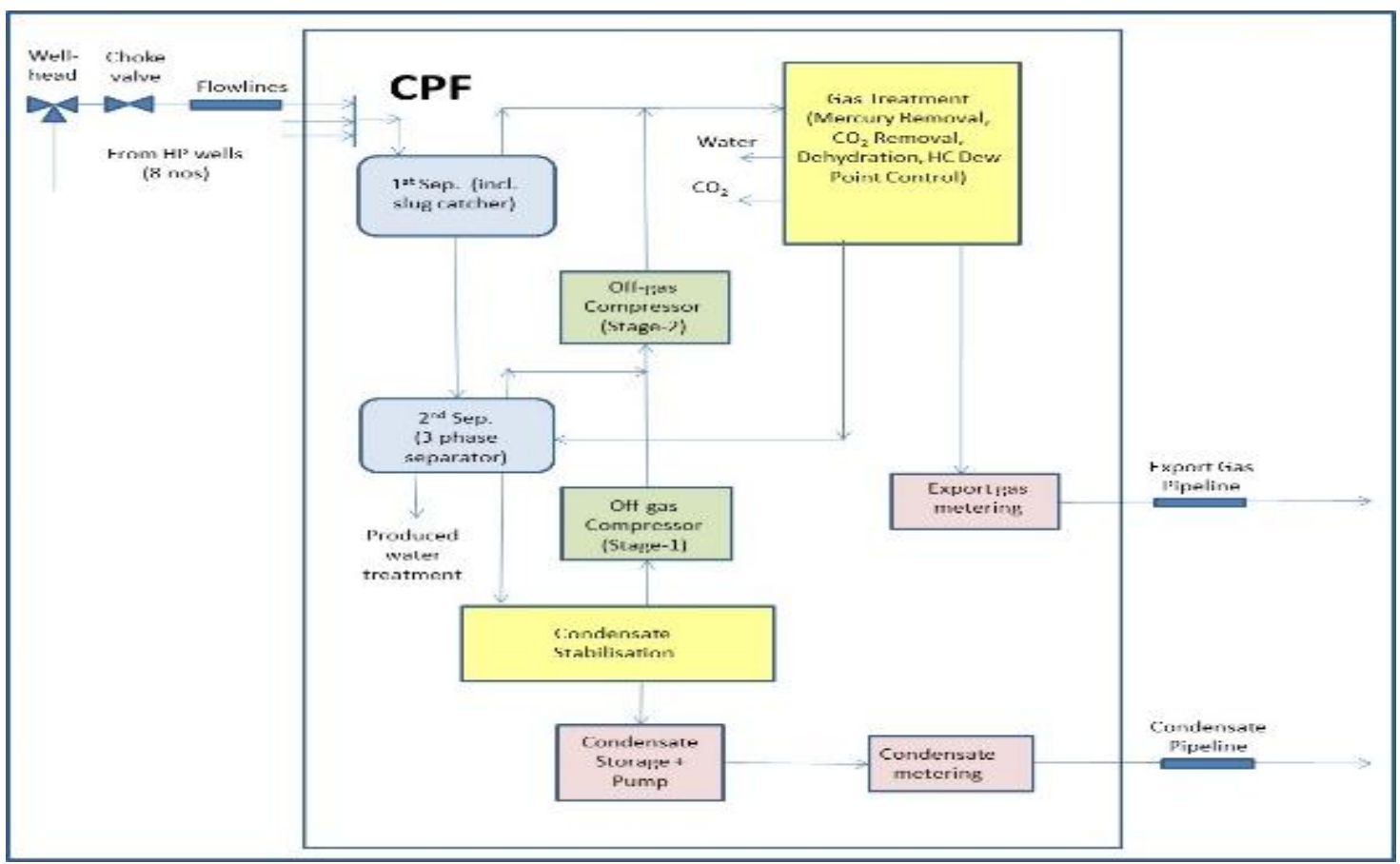

Figure 1 Schematic of the CPF Process Units

\section{Gas Project Design Capacities}

The gas project is designed for a production of 2.7 MSCMD export gas and 10,000 STB/d export condensate. Table 2 explore the design flowrates for the for the process facilities of the gas project.

\section{Table 3: Flowrates Design Production}

\begin{tabular}{|l|l|l|}
\hline Design Capacity & Unit & Value \\
\hline Production from wells (Note 1) & MSCMD & $\begin{array}{l}2.9 \text { (Lean Gas) } \\
3.3 \text { (Rich Gas) }\end{array}$ \\
\hline Gas Export (for gas pipeline design) & MSCMD & 2.7 \\
\hline Condensate Export, maximum & STB/d & 10,000 \\
\hline Water Production, water-cut & $\%$ Vol. & 10 \\
\hline
\end{tabular}


Note1- Includes 0.1 MSCMD of fuel gas.

\subsection{Product Specifications}

The following are the gas and condensate specifications for pipeline export and water specification for disposal.

The export gas specifications for gas are:

- Water dew point:

$$
-12^{\circ} \mathrm{C} \text {. }
$$

- Hydrocarbon dew point at 35 barg:

$$
+10^{\circ} \mathrm{C} \text {. }
$$

- $\mathrm{CO}_{2}$ content:

$<2.0$ mole $\%$.

The pressure of the export gas is 44 barg.
The condensate stabilization unit is designed to achieve a true vapor pressure (TVP) $<0.8$ bara at $60^{\circ} \mathrm{C}$, which gives the Reid vapor pressure $(\mathrm{RVP})<0.4$ bara.

\section{Hydrocarbon Dew pointing control methods:}

The following methods are the all available methods to achieve the required hydrocarbon dew point in the export gas of the gas plant.

\subsection{Joule-Thomson Expansion}

Figure 1 illustrate the hydrocarbon dewpointing control by the J-T effect.

Table 1 reveals the advantages and disadvantages of the joule- Thomason (JT) expansion joint

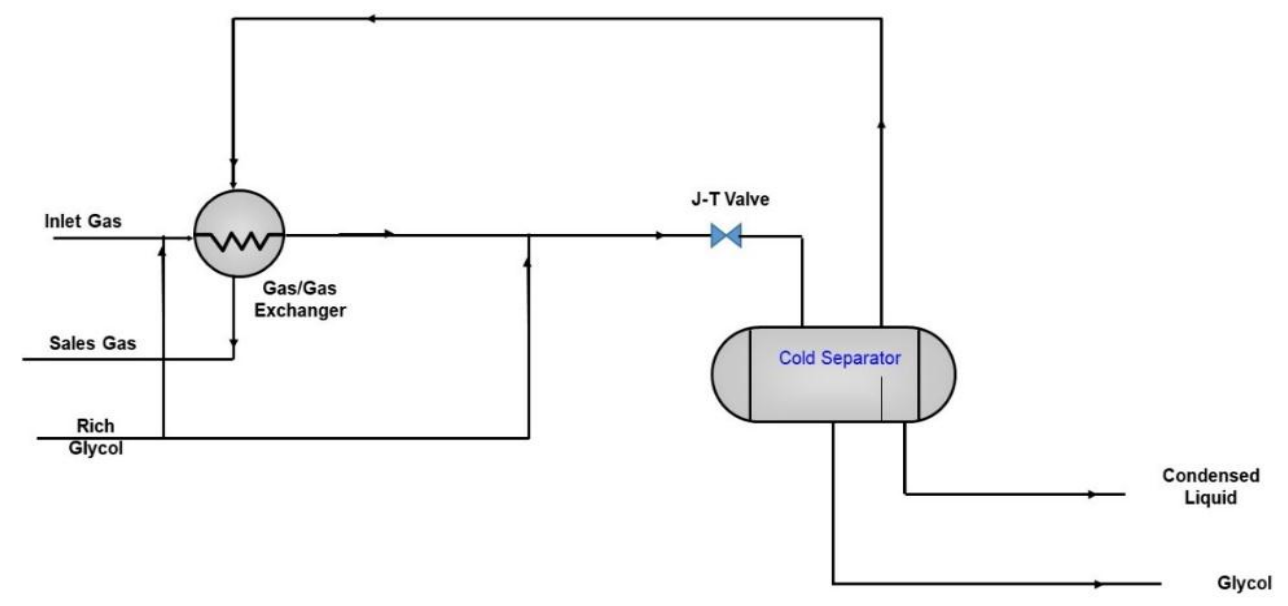

Figure 1: PFD for a typical Joule-Thomson Expansion unit [7]

Table 1: Joule-Thomson Expansion Advantages / Disadvantages [8, 9] 


\begin{tabular}{|l|l|}
\hline $\begin{array}{l}\text { Self-refrigeration process, no external cooling } \\
\text { medium required. }\end{array}$ & High pressure drop. \\
\hline $\begin{array}{l}\text { Outlet gas can achieve hydrocarbon and water } \\
\text { dew point. }\end{array}$ & $\begin{array}{l}\text { Sales gas may require additional } \\
\text { recompression to meet export pressure. }\end{array}$ \\
\hline Has a high flow turndown and ease of operation. & \\
\hline
\end{tabular}

\subsection{Mechanical Refrigeration}

Figure 2 illustrate the hydrocarbon exchanger and/or chiller is the most costdewpointing controlling by mechanical effective means of preventing hydrate refrigeration process. glycol (MEG) formation in a mechanical refrigeration injection at the inlet of the gas-gas heat process. [10].

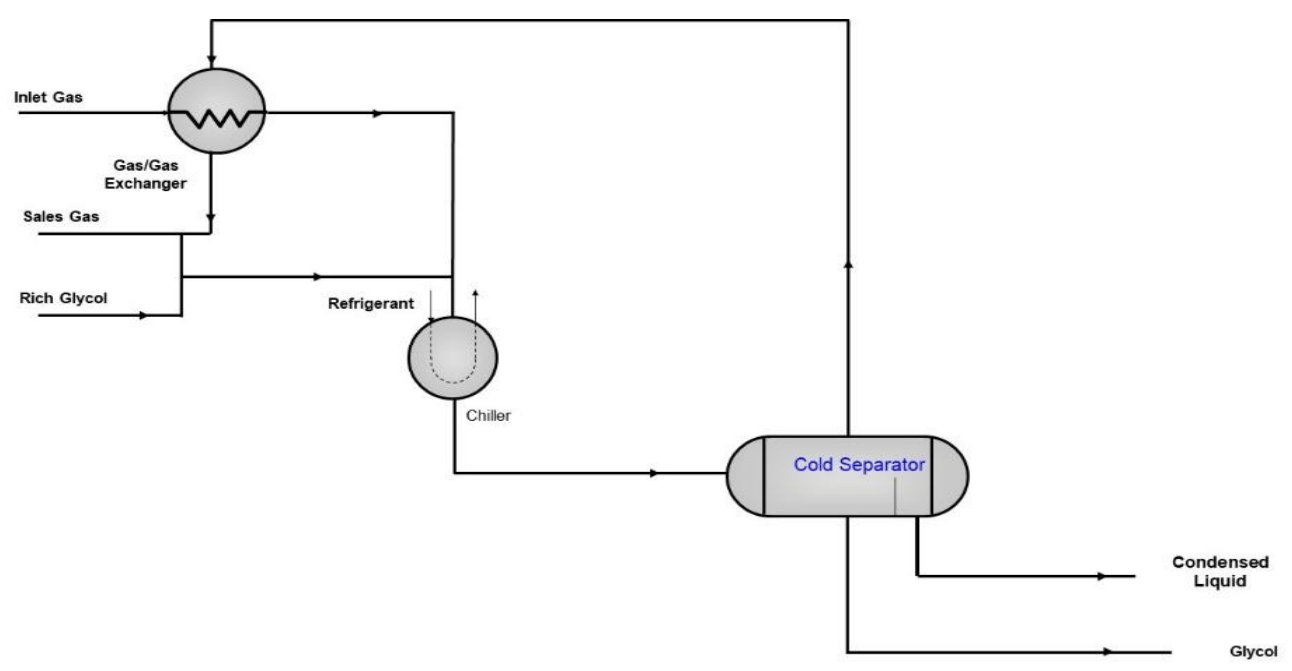

\section{Figure 2: PFD for a Basic Mechanical Refrigeration unit [10]}

Table 2 reveals the advantages and disadvantages of the mechanical refrigeration

Table 2: Mechanical Refrigeration Advantages / Disadvantages [ 11,12]

\begin{tabular}{|ll|l|l|}
\hline Advantages & & Disadvantages \\
\hline Low-pressure drop, sales gas & A refrigeration cycle is required, \\
\hline
\end{tabular}




\begin{tabular}{|l|l|}
\hline recompressor not required. & including refrigerant compressor. \\
\hline $\begin{array}{l}\text { Outlet gas can achieve hydrocarbon and } \\
\text { water dewpoint. }\end{array}$ & $\begin{array}{l}\text { Source of refrigerant and on-site storage } \\
\text { and disposal. }\end{array}$ \\
\hline
\end{tabular}

\subsection{Turbo expansion}

path. A typical expansion process for The turbo-expansion process utilizes a hydrocarbon dewpoint control is shown in turbo-expander to reduce the gas pressure figure 3[13]. with expansion following a near isentropic

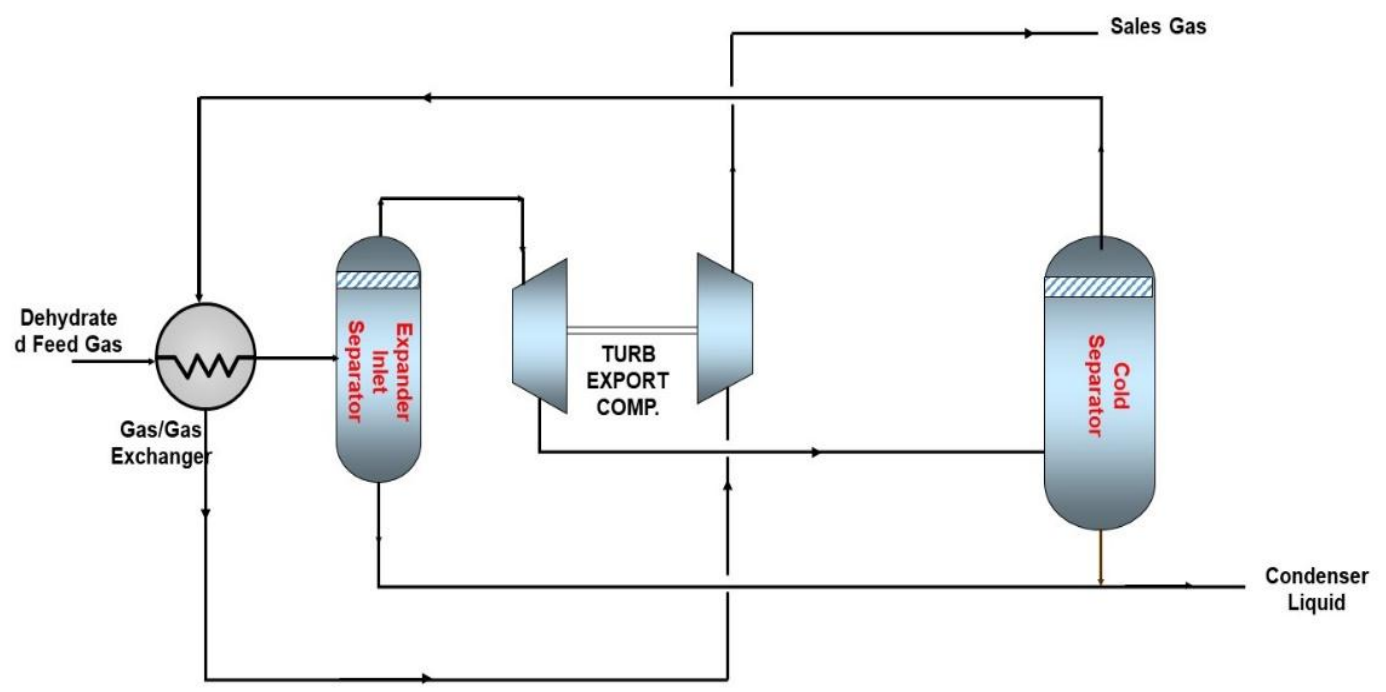

Figure 3: PFD for a Typical Turbo-Expansion Unit [13]

Table 3 shows the advantages and disadvantages of the turbo-expander

Table 3: Turbo-expansion Advantages / Disadvantages [14,15]

\begin{tabular}{|l|l|}
\hline Advantages & Disadvantages \\
\hline $\begin{array}{l}\text { Expander mechanical energy stream } \\
\text { recovered for sales gas compression. }\end{array}$ & $\begin{array}{l}\text { Outlet gas may require an additional } \\
\text { compressor for export. }\end{array}$ \\
\hline $\begin{array}{l}\text { Lower hydrocarbon dewpoint can be } \\
\text { obtained. }\end{array}$ & Stringent upstream dehydration required. \\
\hline
\end{tabular}

\subsection{Swing Adsorption}

Adsorption systems for dewpoint control take advantage of the fact that hydrocarbon adsorption follows the molecular weight of the hydrocarbon; higher molecular weight hydrocarbons are preferentially adsorbed 
while lighter hydrocarbons pass through the adsorbent bed and are available as sales gas [16].

Swing adsorption processes are described by the method of bed regeneration:

- Pressure swing adsorption (PSA)

- Temperature swing adsorption (TSA)

\subsubsection{Pressure Swing Adsorption (PSA)}

PSA systems typically operate at relatively low pressure; in the range of 4.5 to 28.5 bar. The heavy hydrocarbons are removed onto adsorbent bed producing sales gas at feed pressure. The regeneration saturated bed is done by pressure reduction eliminating the heavier hydrocarbons from the adsorbent. In most cases, PSA systems consist of three to four adsorber vessels [17]. material for thermal chlorination. They obtained the optimal condition of PSA purification for removing $\mathrm{C}_{+2}$ components from natural gas as raw material for chloride methane manufactured by thermal chlorination. It has been confirmed in practice that the PSA natural

\subsubsection{Temperature Swing Adsorption (TSA)}

TSA systems normally operate at pressures greater than 28.5 bara. Water and heavier hydrocarbons are adsorbed on a bed of adsorbent, which becomes saturated after a period of operation ranging from 15 minutes to several hours. The saturated bed is regenerated by heating to desorb the water and heavy hydrocarbons. A typical TSA process is shown on figure (4) [19].

Sulan Xia et al. [18] investigated PSA removing $\mathrm{C}_{+2}$ from natural gas as raw

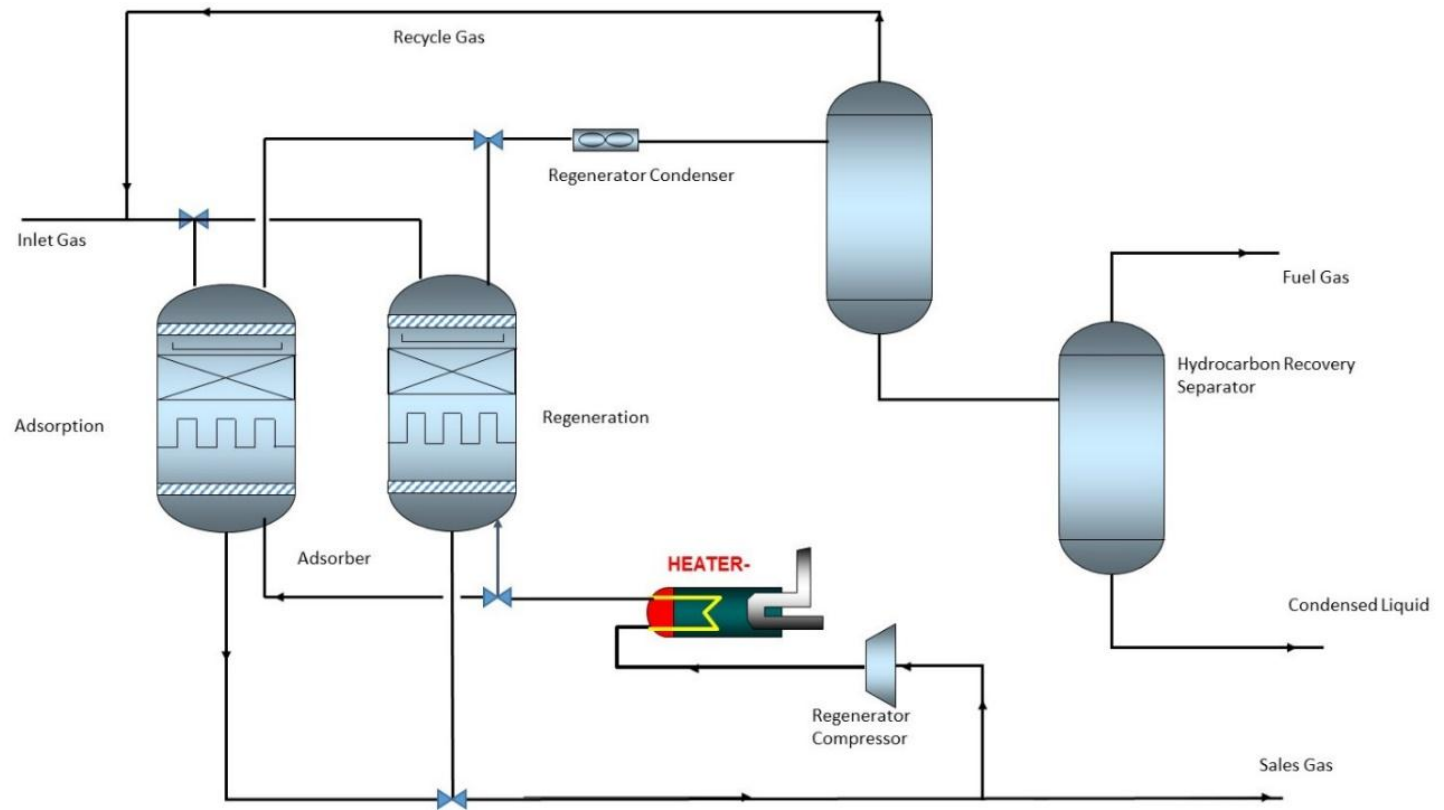




\section{Figure 4: PFD for a Typical TSA Unit [19]}

Table 4 illustrates the advantages and disadvantages of the swing adsorption method

Table 4: Swing Adsorption Advantages / Disadvantages [20,21]

\begin{tabular}{|l|l|}
\hline Advantages & Disadvantages \\
\hline $\begin{array}{l}\text { Low pressure drop compared with Joule- } \\
\text { Thomson or Turbo-Expander processes. }\end{array}$ & $\begin{array}{l}\text { Exhausted adsorbent requires disposal using an } \\
\text { approved environmental method and high } \\
\text { pressure drop compared to refrigeration system }\end{array}$ \\
\hline High operating flexibility. & $\begin{array}{l}\text { Complex controls for batch type regeneration } \\
\text { process. }\end{array}$ \\
\hline $\begin{array}{l}\text { Water and hydrocarbon dew point } \\
\text { control not sensitive to feed gas } \\
\text { composition. }\end{array}$ & $\begin{array}{l}\text { Feed gas temperature required to be less than } \\
45^{\circ} \mathrm{C} \text { at inlet. }\end{array}$ \\
\hline
\end{tabular}

\section{Implementation}

The feed composition of the central process facilities in the gas project will be a mixture of the production from 8 gas wells. The composition reaching the central process facilities will be a mixture of production from each well and may be a combination of rich fluids from one well and lean from another well.

Since each well has different composition in each zone so the mixed composition must achieve the export gas and condensate required flowrates.

Aspen HYSYS steady state simulation software version 10.1 was used to simulate the all hydrocarbon dewpointing control method in the gas plant at different compositions [22]. Rich gas and lean gas compassions from the gas wells were used for the simulation

The selected physical property package for the HYSYS model developed for the gas Project is the Peng-Robinson Equation-of-
State with modified interaction parameters fluid package.

In order to provide confidence in the design to achieve the above specifications some margin has been assumed for each parameter i.e. water dew point $-15^{\circ} \mathrm{C}, \mathrm{HC}$ dew point $6.5^{\circ} \mathrm{C}$ and $\mathrm{CO}_{2}$ content $1.8 \%$ vol. These design margins will allow gas export to continue in the event of off-specification gas production. The online gas chromatograph, part of the fiscal metering unit, will be used to assess the offspecification gas.

Since the export gas specification requires the water dewpoint $\left(<-12^{\circ} \mathrm{C}\right)$ lower than the hydrocarbon dewpoint $\left(<10.5^{\circ} \mathrm{C}\right)$, gas dehydration is required prior to hydrocarbon dewpointing using the J-T expansion, turboexpansion or mechanical refrigeration systems. 
In addition, the limits on the CPF arrival pressure and the gas delivery pressure at the LPG demands minimum pressure drop across the CPF.

The four methods for achieving the required hydrocarbon dew point in the export gas were simulated by HYSYS steady state software. The required energy for each method was extracted from the simulation software. Also, the availability and subtility in the North African countries were highlighted. Finally, the capital cost for each method was mentioned

Finally, a comparison was made to choose the best method to achieve the required export gas specifications

\section{Results}

\subsection{Phase Envelop}

HYSYS simulation steady state software was used to simulate the gas plant based on the rich and lean compositions of the gas wells in the summer case

Figure 5 reveals the phase envelop for the lean gas case while Figure 6 shows the phase envelop for the rich gas case. The phase envelops in Figure $5 \& 6$ compare between the bubble points, dewpoint and the possibility of hydrate formation at different pressures \& temperatures in the gas pretreatment stage and the export gas stage. The gas pretreatment step include separation, gas dehydration, gas sweetening and hydrocarbon dewpointing control.

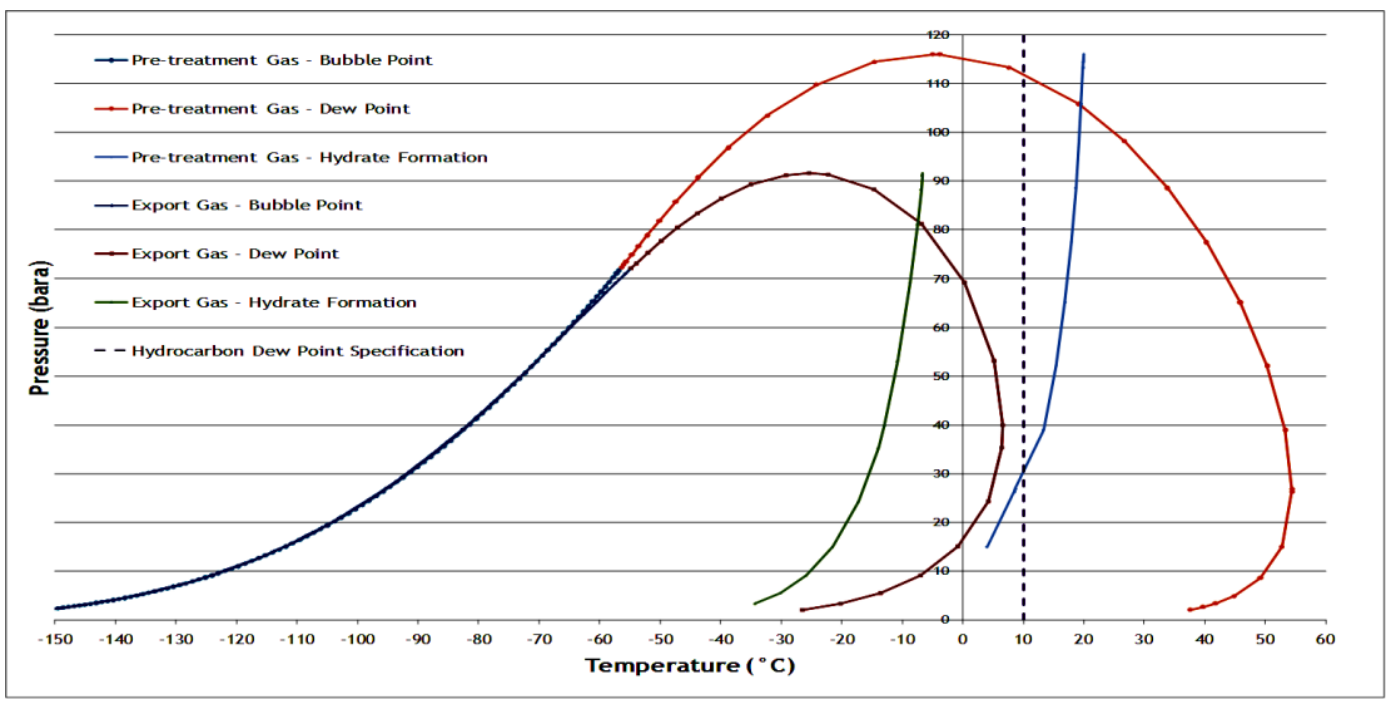

Figure 5 Lean Gas Composition Phase Envelope 


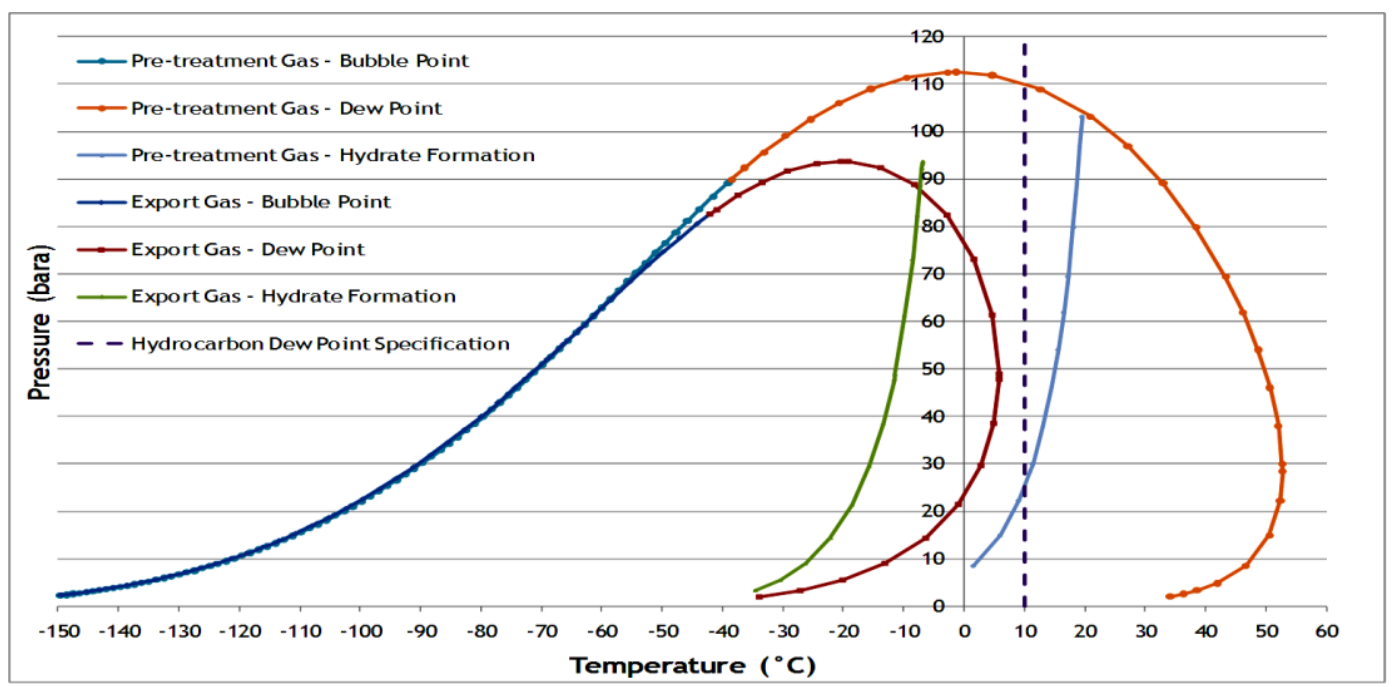

Figure 6 Rich Gas Composition Phase Envelope

6.2 Technical comparison between The J-T expansion has the largest Hydrocarbon dewpointing control recompression duty and makes this system methods

\subsubsection{J-T expansion}

However, the J-T design is less efficient per unit of energy expended. Since a large letdown of pressure from 55 barg to $\sim 20$ barg is anticipated to achieve the $\mathrm{HC}$ dewpoint specification which would also require an additional compressor of substantial size.

This process is well suited to a highpressure reservoir where the ratio between inlet pressure and sales gas pressure is approximately 1.5 ; i.e. no sales gas compression is required. However, although this is initially the case for the gas project, it is expected that the reservoir pressures will decline quickly and will be insufficient for $\mathrm{J}$-T expansion after only a short period of operation. least attractive. The J-T expansion method is not technically suitable for the gas project

\subsubsection{Turbo-expander}

The turbo-expander also needs additional compression requirements to achieve the required export pressure, as the recompression is not $100 \%$ efficient. The turbo-expander with the additional compressor increases the CAPEX and OPEX by an amount dependent on the extent of recompression required downstream. For the gas project, the extra cost may be around $10 \%$ for the relatively relaxed dew point required, but for a more onerous specification, it can be much higher.

The turbo-expansion process is often the preferred solution when the inlet pressure is provided by compression or when the ratio 
of inlet to sales gas pressure is approximately 1.1 to 1.5

In the case of gas projects, the limits for the $\mathrm{CPF}$ arrival pressure and the gas delivery pressure at LPG plant require having a minimum pressure drop across the CPF. A Turbo-expander based dewpoint control would require an additional compressor to meet the export gas delivery pressure at the end.

The turboexpander method is not technically suitable for the gas project

\subsubsection{Mechanical Refrigeration}

Similarly, the mechanical refrigeration system also involves additional CAPEX and OPEX for the external refrigeration plant; the high ambient temperatures also result in larger air cooler sizes. A source of refrigerant is required for first fill and makeup due to losses from the system. However, pressure drop is the least of all the options evaluated and export gas compression is not required.

The mechanical refrigeration method is technically suitable for the gas project

\subsubsection{Swing Adsorption}

The swing adsorption system is not suited to high inlet gas temperatures and complex controls for batch type regeneration.

The swing adsorption method is technically not suitable for the gas project

Table 5 displays the main technical differences between each method used to achieve the required hydrocarbon dew point in the gas plant

Table 5: Technical Comparison between Hydrocarbon Dewpointing control Methods

\begin{tabular}{|l|l|l|l|l|l|}
\hline Item & $\begin{array}{l}\text { Joule- } \\
\text { Thomson } \\
\text { Expansion }\end{array}$ & $\begin{array}{l}\text { Mechanical } \\
\text { Refrigeration }\end{array}$ & $\begin{array}{l}\text { Turbo } \\
\text { expansion }\end{array}$ & $\begin{array}{l}\text { Temperature } \\
\text { Swing } \\
\text { Adsorption }\end{array}$ & $\begin{array}{l}\text { Pressure } \\
\text { Swing } \\
\text { Adsorption }\end{array}$ \\
\hline $\begin{array}{l}\text { Hydrocarbon } \\
\text { dew point } \\
\text { achievement }\end{array}$ & Yes & Yes & Yes & Yes & Yes \\
\hline $\begin{array}{l}\text { Pressure Drop } \\
\text { Recompression } \\
\text { requirements }\end{array}$ & Yes & Low & High & Low & Low \\
\hline $\begin{array}{l}\text { Design } \\
\text { Simplicity }\end{array}$ & Yes & Yes & Yes & No & No \\
\hline Turndown stage & Yes & Yes & No & No & No \\
\hline Refrigeration & No & Yes & No & No & No \\
\hline
\end{tabular}


Vol. 40, No. 2. July 2021

\begin{tabular}{|c|c|c|c|c|c|}
\hline $\begin{array}{l}\text { cycle } \\
\text { requirements }\end{array}$ & & & & & \\
\hline $\begin{array}{l}\text { upstream } \\
\text { dehydration } \\
\text { required }\end{array}$ & No & Yes & Yes & No & No \\
\hline $\begin{array}{l}\text { Feed gas } \\
\text { requirements }\end{array}$ & $\begin{array}{l}\text { Wide range } \\
\text { of flow rate, } \\
\text { lower } \\
\text { flowrate }\end{array}$ & $\begin{array}{l}\text { Wide range of } \\
\text { flow rate, } \\
\text { lower flowrate }\end{array}$ & $\begin{array}{l}\text { High } \\
\text { flowrate } \\
\text { only }\end{array}$ & $\begin{array}{l}\text { Inlet pressure } \\
\text { above } 28.5 \text { bar } \\
\text { Sensitive to gas } \\
\text { composition, } \\
\text { Feed } \\
\text { temperature less } \\
\text { than } 45 \mathrm{C}\end{array}$ & $\begin{array}{l}\text { Inlet pressure } \\
\text { from } 4.5 \text { to } \\
28.5 \text { bar } \\
\text { Sensitive to } \\
\text { gas } \\
\text { composition, } \\
\text { Feed } \\
\text { temperature } \\
\text { less than } 45 \mathrm{C}\end{array}$ \\
\hline $\begin{array}{l}\text { Operation } \\
\text { flexibility }\end{array}$ & Flexible & Flexible & Complicated & Flexible & Flexible \\
\hline Control System & Simple & Simple & Simple & Complex & Complex \\
\hline $\begin{array}{l}\text { Regeneration } \\
\text { system } \\
\text { Requirements }\end{array}$ & No & No & No & Yes & Yes \\
\hline $\begin{array}{l}\text { Refrigeration } \\
\text { Cycle }\end{array}$ & No & Yes & No & No & No \\
\hline $\begin{array}{l}\text { Environmental } \\
\text { impact }\end{array}$ & No & No & No & Yes & Yes \\
\hline $\begin{array}{l}\text { Proven } \\
\text { Technology }\end{array}$ & Yes & Yes & Yes & Yes & Yes \\
\hline
\end{tabular}

From table 5 it can be noticed that the best drop. simple in operation, simple control method for the gas plant is the mechanical system and no need for any compression refrigeration method as it has lower pressure package. 
6.2 Economical comparison between hydrocarbon dew point in the gas plant. The Hydrocarbon dewpointing control required energy for each method was taken methods from the simulation of each method

Aspen HYSYS steady state simulation Figure 7 displays the required energy for software version 10.1 was used to simulate each hydrocarbon dew pointing control the all hydrocarbon dewpointing control method for the gas project. methods to achieve the required

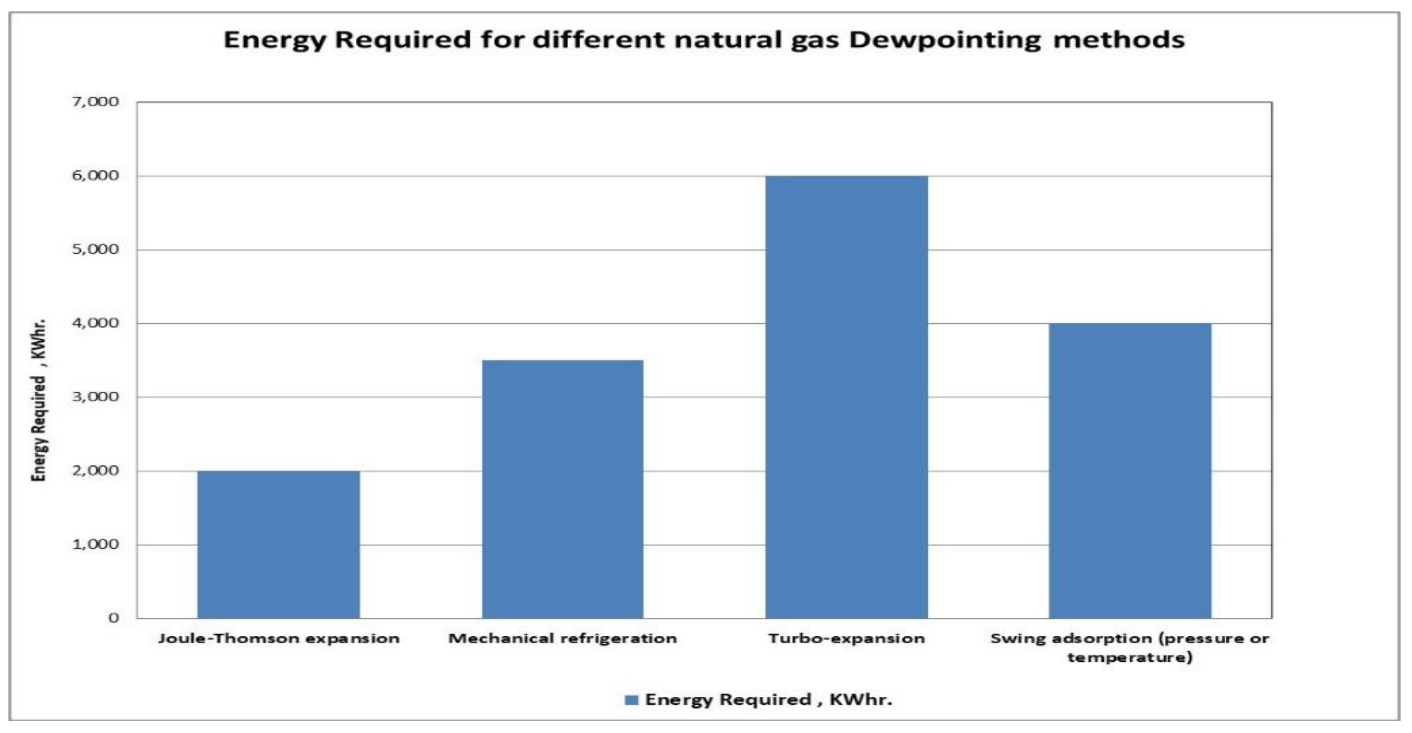

Figure 7: Energy Required for different Natural Gas Hydrocarbon Dewpointing Control Methods

The capital cost of each method required to achieve the hydrocarbon dew point in the gas plant was taken from the HYSY simulation program and from different vendors all over the world. Figure 8 illustrates the capital cost in million USD for each hydrocarbon dew pointing control method for the gas project 
Vol. 40, No. 2. July 2021

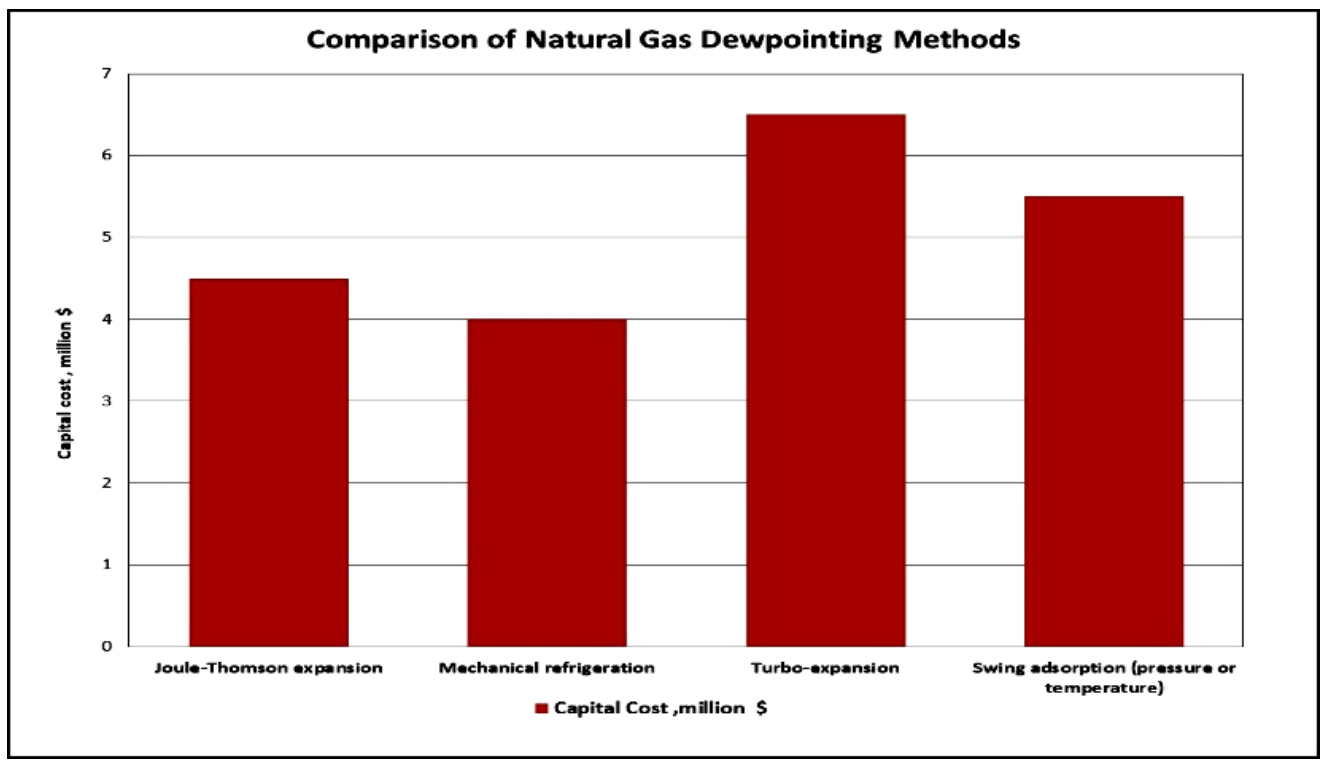

Figure 8: Capital Cost for different natural gas hydrocarbon dew pointing control methods

6.3 Comparison Summary between The comparison in this table is based on the Hydrocarbon dewpointing control capital cost for each method, the availability methods $\&$ suitability in the North African countries,

Table 6 summarizes the main technical and commercial differences between the hydrocarbon dew pointing control methods needed to achieve the required hydrocarbon dew point in the export gas of the gas plant. energy required for each method and the limitations for each method.

From the table, it can be noticed that the best method technical and economically is the mechanical refrigeration method 
Vol. 40, No. 2. July 2021

\begin{tabular}{|c|c|c|c|c|c|}
\hline \multicolumn{6}{|c|}{ Comparison between Hydrocarbon Dew pointing control methods } \\
\hline Technology & $\begin{array}{c}\text { Joule-Thomson } \\
\text { expansion }\end{array}$ & $\begin{array}{l}\text { Mechanical } \\
\text { refrigeration }\end{array}$ & Turbo-expansion & $\begin{array}{c}\text { Swing adsorption } \\
\text { (pressure or } \\
\text { temperature) }\end{array}$ & Remarks \\
\hline \begin{tabular}{|c|} 
Energy Required , \\
KWhr.
\end{tabular} & 2,000 & 3,500 & 6,000 & 4,000 & \\
\hline $\begin{array}{l}\text { Suitability in } \\
\text { North African } \\
\text { countries }\end{array}$ & No & Yes & Yes & No & \\
\hline Design Limitation & Feed Pressure & $\begin{array}{c}\text { external } \\
\text { refrigeration } \\
\text { plant is needed }\end{array}$ & $\begin{array}{l}\text { - Feed Pressure } \\
\text { - Complex Operation }\end{array}$ & $\begin{array}{l}\text { - Complex controls for } \\
\text { batch type regeneration } \\
\text { - Feed inlet temperature } \\
\text { - Environmental } \\
\text { problems }\end{array}$ & $\begin{array}{l}\text { - Joule Thomson Requires } \\
\text { gas export compressor to } \\
\text { increase the export gas } \\
\text { pressure and used only for } \\
\text { short period of } \\
\text { operation(startup) } \\
\text { - Turbo expander Requires } \\
\text { gas export compressor to } \\
\text { increase the export gas }\end{array}$ \\
\hline $\begin{array}{c}\text { North Africa } \\
\text { Reference }\end{array}$ & No & Yes & Yes & NA & \\
\hline $\begin{array}{l}\text { Capital Cost } \\
\text {,million } \$\end{array}$ & 4.5 & 4 & 6.5 & 5.5 & $\begin{array}{l}\text { The Capital cost include the } \\
\text { cost of the export } \\
\text { compressor needed for the } \\
\text { turbo expander and joule } \\
\text { Thomson methods. }\end{array}$ \\
\hline
\end{tabular}

\section{Table 6: Comparison between hydrocarbon dew pointing control methods}

\section{Conclusions \& recommendations}

Based on the technical and commercial comparison between the all available methods in the international market to achieve the required hydrocarbon dew point of the export gas in the gas project, it is confirmed that mechanical refrigeration is the best option for controlling the hydrocarbon dewpoint in the gas project.

$\begin{array}{ll}\text { Abbreviation } & \begin{array}{l}\text { Description } \\ \text { hydrocarbon dew point } \\ \text { Central Processing Facility }\end{array} \\ \text { CPF } & \text { Hydrocarbon dew point } \\ \text { HDP } & \text { Joule-Thomson } \\ \text { J-T } & \text { Liquefied Petroleum Gas } \\ \text { LPG } & \text { Monoethylene Glycol } \\ \text { MEG } & \text { Operating Expenditure } \\ \text { OPEX } & \text { Pressure Swing Adsorption } \\ \text { PSA } & \text { return on investment Swing } \\ \text { ROI } & \text { Temperature Adsorption } \\ \text { TSA } & \text { A }\end{array}$

\section{Nomenclature:}
Abbreviation
CAPEX
escription
CHDP
Capital Expenditure
Cricondentherm 


\section{References}

[1] Donald, L., 'Handbook of Natural Gas Engineering', McGraw- Hill Book Company, New York, (2004).

[2] Dustman, T., Drenker, J., Bergman, D.F., Bullin, J.A., "An Analysis and Prediction of Hydrocarbon Dew Points and Liquids in Gas Transmission Lines," Proceedings of the Eighty-Fifth GPA Annual Convention, Dallas, Texas, USA, (2006).

[3] Tulsa, Oklahoma, GPSA Engineering Data Book, 'Gas Processors Suppliers Association", $11^{\text {th }}$ edition, (2004).

[4] Poling, B.E., Prausnitz, J.M., Connell, J.P., "The Properties of Gases and Liquids", 5th edition, (2001).

[5] GPA Standard 2261, "Analysis for Natural Gas and Similar Gaseous Mixtures by Gas Chromatography", Gas Processors Association, Tulsa, Oklahoma, USA, (2000).

[6] Towler, G., Sinnott, R.K.," Chemical Engineering Design: Principles, Practice and Economics of Plant and Process Design", 2.ed. Burlington: Butterworth-Heinemann, Elsevier, (2012).

[7] Cowper, C.J., "Natural Gas Hydrocarbon Dew Point; Comparison of Measurement and Calculation Methods", 2nd Gas Analysis Symposium and Exhibition 2002, Maastricht, Belgium, (2002).

[8] Warner,H., Leamer ,E., Spence, A., Bone R., Hubbard R., Bernos J., Kriel W., "Hydrocarbon dewpoint determination of lean natural gases,", in Proceedings 80th Annual Convention, Gas Processors Association, (2001).

[9] Starling, K. E., "Analysis of Processes Occurring in Manual Chilled
Mirror Hydrocarbon Dew Point Equipment," Proceedings of the 2007 [10] AGA Operations Conference, American Gas Association, Washington, DC, USA, April 24-26, (2007).

[10] Chatterjee, N., Kinard, G.E., Geist, J.M., "Maximizing Production in Propane Precooled Mixed Refrigerant LNG Plants," Seventh Conference on Liquefied Natural Gas, Jakarta, Indonesia, May 15-19, (1983).

[11] Bannell, J. L. K, Dixon, A. G., Davies, T. P., "The monitoring of hydrocarbon dew Point', International Congress of Gas Quality, Groningen, The Netherlands, (1986).

[12] Mokhatab, S., Poe, W. A., "Handbook of natural gas transmission and processing", Gulf Professional Publishing, (2012).

[13] Wilkinson, J.D., Hudson, H.M., "Turboexpander Plant Designs Can Provide High Ethane Recovery without Inlet $\mathrm{CO}_{2}$ Removal," $32^{\text {nd }}$ Annual Gas Conditioning Conference, Norman, OK, (1982).

[14] Agahi ,R. R., Ershaghi ,B., "Engineering of Turboexpander Compressor Units for Offshore Installation," Fifth International Congress on Fluid Machinery, The Hague, Netherlands, (1993).

[15] Rusten ,B., Gjertsen ,L., Solbraa, E., Kirkerød ,T., Haugum, T., Puntervold ,T., "Determination of the phase envelope - crucial for process design and problem solving" ,GPA conference, Grapevine, Texas, USA, (2012)

[16] Xia, S., Zhu, J., Zeng, X., Feng, Z., Cheng, X., " Study on Pressure Swing Adsorption Removing C+2 from Natural Gas as Raw Material for 
Thermal Chlorination', Journal of Natural Gas Chemistry 13, 53-57, (2004).

[17] Michalsen, K., Nævdal, H.S., "'Fundamentals of natural gas processing - hydrocarbon dew point meter modelling', Publication of the Department of Energy and Process Engineering, Norwegian University of Science and Technology, (2014).

[18] Sulan,X., Jiahua , Z., Xiaobin ,Z. , Zhaohua, F., Xinyu ,C., "Study on Pressure Swing Adsorption Removing $\mathrm{C}+2$ from Natural Gas as Raw Material for Thermal Chlorination", Journal of Natural Gas Chemistry Vol. 13 No. 1 ,(2004).

[19] Kim, D. J., Kim, J. W., Yie ,J. E., Moon ,H., "Temperature-programmed adsorption and characteristics of honeycomb hydrocarbon adsorbers,",Industrial and Engineering Chemistry Research, vol. 41, No. 25, 6589-6592, (2002).

[20] Al Wahedi, Y., Torres, A., Al Hashimi, S., Dowling, N., Daoutidis ,P., Tsapatsis, M., "Economic assessment of Temperature Swing Adsorption systems as Claus Tail Gas Clean Up Units", Chemical Engineering Science, 126, 186-195, (2015).

[21] M., Ridge, A., Lander, D., Laughton, A., "Comparison of Methods for the [22] Measurement of Hydrocarbon Dew point of Natural gas," NPL Report AS 3, (2007).

Aspen Tech., “Advanced Process Modeling Using HYSYS”, 2015. 


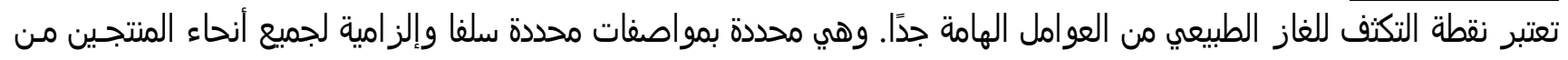

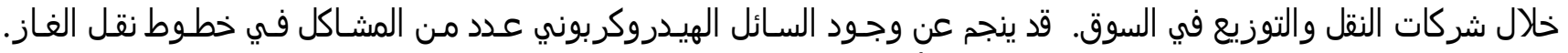

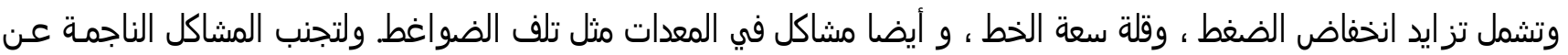
تكثف الغاز يتطلب ذلك مواصفات التشغيلية الحالية لخطوط نقل الغناف الغاز أن يتم تشغيلها فوق نقطة الذدى في الهيدروكربون (DPH)

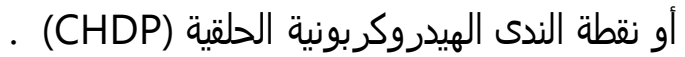

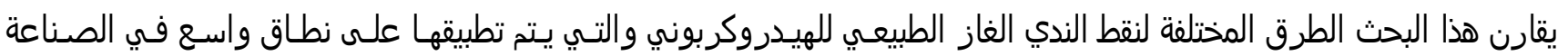

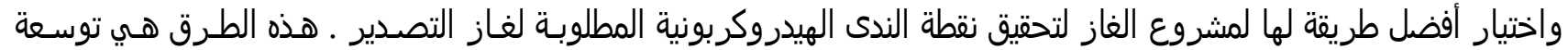

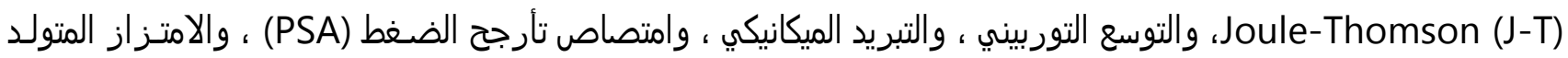

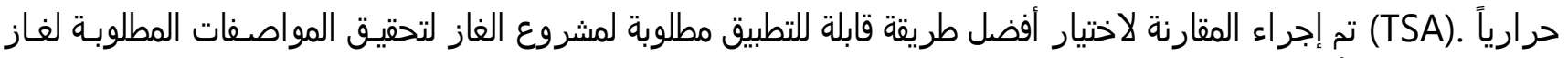

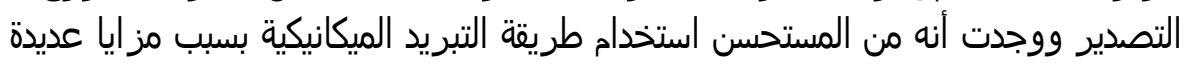

